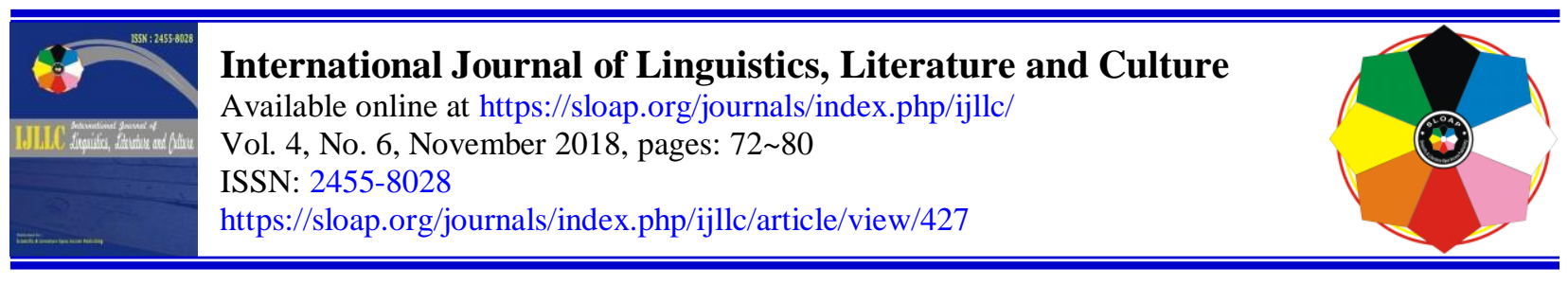

\title{
Repetition in Indonesian Political Language
}

\author{
David Samuel Latupeirissa ${ }^{a}$ \\ I Ketut Darma Laksana ${ }^{\text {b }}$ \\ Ketut Artawa $^{c}$ \\ I Gusti Ayu Gde Sosiowati ${ }^{\mathrm{d}}$
}

\section{Article history:}

Received: 18 July 2018

Accepted: 30 September 2018

Published: 30 November 2018

\section{Keywords:}

critical discourse analysis;

language style;

political language;

repetition;

Soekarno;

\section{Author correspondence:}

David Samuel Latupeirissa, STIBA Mentari Kupang, East Nusa Tenggara, Indonesia,

Doctoral Program of Linguistics, Universitas Udayana, Denpasar, Indonesia,

Email address: latupeirissadavid1@gmail.com

\begin{abstract}
This is a critical discourse study that tried to reveals repetition phenomena in political language. We conducted the study by examining the language of Soekarno, as an Asian politician, as well as a nation founder and the first president of Indonesia, where this study was conducted on. Data were gained by documentation method, and be analyzed by applying Critical Discourse Analysis theory that proposed by Fairclough. We found that repetition as a language style used by Indonesian politician, in this case, Soekarno, was meant for the rhetorical device and as an ideology vehicle device.
\end{abstract}

2455-8028 ${ }^{\circledR}$ Copyright 2018. The Author. This is an open-access article under the CC BY-SA license (https://creativecommons.org/licenses/by-sa/4.0/) All rights reserved.

\section{Introduction}

The critical use of discourse analysis (CDA) is leading to the development of a different approach to understanding political language. The text of political language, whether written or oral, is a multidimensional structure, and any text is layered, like a sheet of thick plywood consisting of many thin sheets lying at different angles to each other. The basics of a text consist of syntax and lexicon; its grammar, morphology, phonology, and semantics. The layer of syntax and lexicon have included repetition as a language style. This also leads to a particular semantic meaning.

The phenomena had appeared in Soekarno's Political Language (SPL). Soekarno was a founder, as well as the first president of Indonesia, where this study was conducted on. He was a great politician in Indonesia history. Based on the research conducted by Latupeirissa (2018), the main form characters of SPL was repetition.

${ }^{a}$ STIBA Mentari Kupang, NTT, Indonesia

${ }^{\mathrm{b}}$ Universitas Udayana, Denpasar, Indonesia

${ }^{\mathrm{c}}$ Universitas Udayana, Denpasar, Indonesia

${ }^{\mathrm{d}}$ Universitas Udayana, Denpasar, Indonesia 
Counting such thoughts, we have chosen SPL as research object to examine the whyness of politician applying repetition in delivering a political speech. The repetition is a layer of syntax and lexicon that hide a semantical secret. Revealing the whyness, we believe, will bring a new understanding in language and politic matter.

Another reason why we have chosen the political language of Soekarno is as follow. There is undeniable fact about Indonesia as a nation with high rate corruption cases. The highest rate of corruption in Indonesia, in fact, has acted by politicians' (Tim Penyusun Laporan Tahunan KPK 2016). Indonesia scored 37 points out of 100 on the 2017 (Corruption Perceptions Index, 2017). Corruption Index in Indonesia averaged 25.79 Points from 1995 until 2017. It shows a reality that in the past, the political language, especially the political language of Soekarno, is believed as a tool of humanity in building and unifying a nation. On the contrary, nowadays, most political language is being used as a means to deceive people. In line with repetition as a language style that mostly used by a politician, in the past, repetition was used for the sake of nation while nowadays, repetition is only used to, we will say, 'destroy' nation.

\section{Research Methods}

In this section, before presenting our research method, we present a brief theory that is applied in this research. We applied CDA theory that proposed by Fairclough (1989, 1995, 2005, 2006), as the main theory. We also applied the theory of Hermeneutics to have a deeper examination of the research object. CDA Fairclough (1989, 1992, 1995, 2005, 2006) analyzes discourse critically through three stages namely microanalysis, meso analysis and macro analysis (Manmeet and Bharathi 2016).

Fairclough (1989 \& 1992) puts forward three stages of discourse analysis, they are also known as description, interpretation, and explanation respectively. Description, concerned with the analysis of text, is the linguistic description of the language text in terms of linguistic devices and concepts mainly by making use of Systemic Function Grammar. Interpretation, concerned with the analysis of discourse practice, is an interpretation of the relationship between the productive and interpretative discursive processes and the text, with attention paid to the situational contexts in which text production, distribution and consumption occur. Explanation, concerned with the analysis of social practice, is an explanation of the relationship between the discursive processes and social processes, in other words, it aims to analyze the discourse within a wider social practice or identify the social determinants and social effects of the discourse, as Fairclough (1989) believes that explanation of social practice involves an analysis whose "objective... is to portray a discourse as part a social process, as a social practice, showing how it is determined by social structures, and what reproductive effects discourses can commutatively have on those structures, sustaining them or changing them" (p.163). The three-dimensional concept of discourse and the corresponding analytical methods constitute the three-dimensional model of Fairclough, is shown in Figure 1.

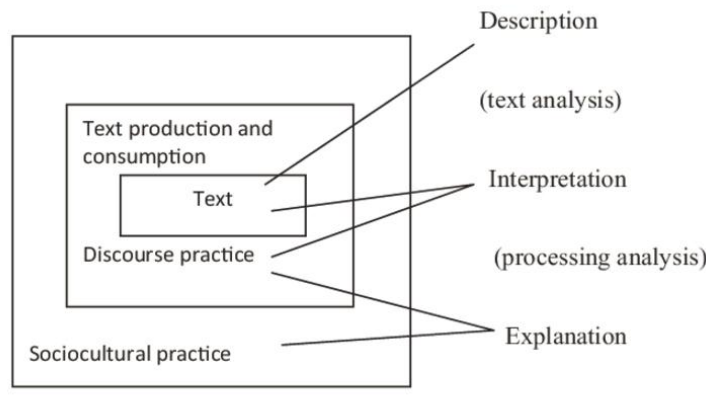

(social analysis)

Figure 1. Three Dimensional Model of Fairclough's CDA

Just as the three dimensions of discourse are interrelated with each other, these three stages of discourse analysis also enjoy close interconnection, which is shown in the fact that the analysis of discursive practice serves as a bridge between text and social practice analysis. According to Fairclough (1992), a special feature of this three-dimensional approach to discourse analysis is that "the link between socio-cultural practice and text is mediated by discursive practice" (p.9). Fairclough (1995) values the feature as one of the significant principles of CDA, that is, analysis of

Latupeirissa, D. S., Laksana, I. K. D., Artawa, K., \& Sosiowati, I. G. A. G. (2018). Repetition in Indonesian political language. International Journal of Linguistics, Literature and Culture, 4(6), 72-80. 
text, that be focused on repetition, should not be artificially isolated from analysis of institutional and discursive practices within which texts are embedded.

Seen from the above discussion, it can be concluded that the analysis of any specific discourse like repetition style in political language requires all the three interrelated stages, which cannot be separated from one another. The point can be well justified by Fairclough's (1992) comments on the interrelationship between description and interpretation, "description is not as separate from interpretation as it is often assumed to be. As an analyst and as an ordinary text interpreter, one is inevitably interpreting all the time, and there is no phase of analysis which is pure description" (p.199).

Related to this study, each discourse appeared in the text, conversation, or whatever, cannot be seen as something natural, reasonable and neutral (Fairclough, 2005). They are power fighting. In relation to this study, SPL was viewed as a form of struggle and fight. Further, Fairclough (1995a) stated that text is judged as domain representation, the significance of the world and experience which is opened to various interpretations. The simplest discourse is a form of combat power. Thus, based on the critical approach, any analysis of the discourse is always associated with the dimensions of power (cf. Latupeirissa 2014). In other words, repetition found in SPL contains certain meaning related to power and must be revealed using three-dimensional analysis.

Next, since the analysis contains interpretation, we applied the theory of hermeneutic to have a deeper interpretation of repetition phenomena in SPL. As we have considered, it is normal since linguistics and hermeneutics are often regarded as two mutually exclusive scholarly discipline. Hermeneutics as the methodology of interpretation is concerned with problems that arise when dealing with meaningful human actions and the products of such actions, most importantly text of SPL. As a methodological discipline, it offers a toolbox for efficiently treating problems of the interpretation of human actions, texts, and other meaningful material.

Hermeneutics looks back at a long tradition as the set of problems it addresses have been prevalent in human life, and have repeatedly and consistently called for consideration: interpretation is a ubiquitous activity, unfolding whenever humans aspire to grasp whatever interpret and they deem significant. Due to its long history, it is only natural that both its problems and the tools designed to help solve them have shifted considerably over time, along with the discipline of hermeneutics itself.

We have seen that interpretation of text goes beyond the interpretation of simple or complex sentences since it crucially includes a number of inferences that are necessary in order to glean the meaning of repetition in SPL. Text interpretation as a goal-directed activity can assume different forms but must be distinguished from highlighting the significance of interpretation. In fact, a series of serious misunderstandings and confusions can be easily avoided, if a clear distinction is made between interpretation as an activity directed at the appropriation of the meaning of SPL and textual criticism as an activity that is concerned with the significance of a text with respect to different values.

Next, the following is a description of the method we applied. We have conducted this study based on the view of phenomenology philosophy. It begins with an exploration of phenomena (what presents itself to us in conscious experience) as a means to finally grasp the absolute, logical, ontological and metaphysical Spirit that is behind phenomena. We explored the phenomena, in this case, repetition in SPL, and describe as it is.

We took a corpus of Soekarno speech document from the office of Indonesia Republic National Archives (IRNA) in South Jakarta- Indonesia, and from the National Library of the Indonesia Republic in Central Jakarta. The data source was taken from those places as mentioned above since both places were the places where original state documents were kept.

Research procedures were conducted through following steps; First, from IRNA and National Library of Indonesia Republic, the researchers took some political speech texts (documents) as a portrait of the entire Soekarno's speech text. The documents were corpora. Second, from the corpora, we took a document based on purposive sampling technique. The chosen document was a corpus that filtered into research data.

Corpus of the SPL was his political speech on August, $17^{\text {th }}$ 1965. The title of this speech was Tahun Berdikari'. This was taken as the corpus for some reasons as follows: 1) Soekarno himself stated that August $17^{\text {th }}$ 's speeches were the most important speech (Siswo, 2014). 2) The 'Tahun Berdikari' speech was the only speech that contains a summarise of 19 August-speeches, that delivered since August, $17^{\text {th }} 1945$ to August, $17^{\text {th }} 1959$. In other words, it has got a complete ideology of SPL. 3) In 1965, Indonesia faced critical times as communist party did maneuver to kill some Indonesia generals. This was followed by a tragedy of large-scale killings and civil unrest which occurred over several months, targeting communist sympathizers, ethnic Chinese and alleged leftists, often at the instigation of the armed forces and government (Melvin, 2017). Hermeneutically, as the president, and as the founding father, Soekarno has felt crucial situation before the tragedy happened. For sure, he constructed his best political speech by that year that delivered on August, $17^{\text {th }} 1965$. 
Third, we identified data based on problems research. Fourth, we presented and described data to be analyzed based on Fairclough CDA theory principals, namely microanalysis, meso analysis, and macro analysis. Microanalysis investigated the repetition of SPL, meso analysis investigated the ideology meaning behind the language form that used in SPL and the whyness of its phenomena. Macro analysis investigated social change briefly. Those three analyses are basic analysis in conducting conclusion for answering scientific problems discussed.

\section{Results and Analysis}

In this section, we discuss three important parts namely the analysis of text form that shows repetition as the main character of SPL form; the analysis of its purpose that is as a rhetoric device; and the analysis of its purpose that is as a vehicle of planting ideologies. The first analysis draws our discussion into the second and the third parts. In the end, based on the discussion on this section, we conclude some important points relate to our findings.

Based on our research, the prominence characteristic form of the SPL is reflected in the used of repetition. Repetition is a major rhetorical strategy for producing emphasis, clarity, amplification, or emotional effect. It is a broad term, which is used in all languages. It is not specified to a certain field. Tannen (2007) defines repetition as "the recurrence of words and collocations of words in the same discourse". The political speech is one of the genres that uses repetition and relies on it heavily. Politicians utilize "repetition" not only to echo its original function, which is confirmation. Rather, they believe in its strong effect of persuasion. Therefore, they resort to it either to convince their audience of a certain critical and political events, or to propose a definite previous vision, so it is more absorbed by people. Soekarno, as a politician, also used it to persuade people.

On the data, as we have stated above, the phenomenon of the use of stylistic repetition in SPL has been found as prominence characteristic. It appeared 206 (two hundred and six) times. This phenomenon spread in 145 segments. In other words, at least, in a segment or in each paragraph, Soekarno used more than one repetition style in his political speech. It was apparent through the number of repetition that exceeds the number of segments contained in the text of SPL. Repetition style has got the largest occurrence presentation than any other language style used by Soekarno. This phenomenon reflects the personality of the Soekarno as a charismatic figure, manful, and accurate who always tried to persuade people for a democratic purpose. In the following table, we display some examples of total data gained that shows repetition phenomena in SPL. The data in the example table is taken from segment one to segment five of SPL.

Table 1

Example of total 206 repetition phenomena found in SPL

\begin{tabular}{|c|c|c|}
\hline No. & Data & Segment \\
\hline 1 & Tjamkanlah saudara- saudara! Tjamkanlah, Tjamkanlah & 1 \\
\hline 2 & $\begin{array}{l}\text { Hari ini genap } 20 \text { tahun Proklamasi Kemerdekaan! Hari ini tepat } \\
20 \text { tahun kita menjadi bangsa merdeka! Hari ini djangkap } 20 \\
\text { tahun... }\end{array}$ & 1 \\
\hline 3 & ...Negara kita! Negara Merdeka, Negara Republik Indonesia. & 1 \\
\hline 4 & Hari ini, detik ini... & 2 \\
\hline 5 & $\begin{array}{l}\text {...rasa hatiku luluh menjadi satu dengan hati Rakyatku, dengan hati } \\
\text { Tanah-airku, dengan hati Revolusi. }\end{array}$ & 2 \\
\hline 6 & $\begin{array}{l}\text { Fikiran dan perasaanku berpadu dengan fikiran dan perasaan } \\
\text { semua... }\end{array}$ & 2 \\
\hline 7 & $\begin{array}{l}d i \text { kota-kota dan } d i \text { desa-desa, } d i \text { gunung-gunung dan } d i \text { pantai- } \\
\text { pantai }\end{array}$ & 2 \\
\hline 8 & $\begin{array}{l}\text {...dari Sabang sampai Merauke, dari Banda Aceh sampai } \\
\text { Sukarnapura... }\end{array}$ & 2 \\
\hline
\end{tabular}

Latupeirissa, D. S., Laksana, I. K. D., Artawa, K., \& Sosiowati, I. G. A. G. (2018). Repetition in Indonesian political language. International Journal of Linguistics, Literature and Culture, 4(6), 72-80. https://doi.org/10.21744/ijllc.v4n6.427 


\begin{tabular}{clc}
\hline 9 & Hari ini..., hari ini..., hari ini..., hari ini..., hari ini..., hari ini... & 2 \\
\hline 10 & ... bukan Sukarno, bukan Subandrio, bukan Ali, bukan Idham, & 2 \\
& bukan Aidit, bukan Dadap, bukan Waru, bukan Suto, bukan Noyo, \\
& bukan Sarinah, bukan Fatimah... \\
\hline 11 & ...bukan Kepala Negara, bukan Menteri, bukan pegawai, bukan \\
& buruh, bukan petani, bukan nelayan, bukan mahasiswa, bukan & 2 \\
& seniman, bukan sarjana, bukan wartawan... & 2 \\
\hline 12 & ... bukan semata-mata politik, bukan melulu ekonomi, bukan hanya & 3 \\
\hline 13 & kebudayaan, bukan mligi ilmu, bukan militer thok... & 4 \\
\hline 14 & Allahuakbar, Allahuakbar, Allahuakbar & 4 \\
\hline 15 & Kalau hari ini..., dan kalau hari ini.... Dan kalau di dunia ini... & 4 \\
\hline 16 & Aku bangga..., aku bangga & 4 \\
\hline 17 & ... mencerca kita, mengejek kita, mentertawakan kita... & 5 \\
\hline 18 & Resapkanlah, endapkanlah, renungkanlah & 5 \\
\hline 19 & Tergantung..., tergantung... \\
\hline 20 & Manakala..., manakala..., manakala..., manakala..., manakala..., \\
\hline 21 & Kita melempem..., kita lembek..., kita menjerah... \\
\hline
\end{tabular}

Examining the 206 (two hundred and six) data, we interpreted the purpose of repetition style that used in SPL. Firstly, from the hermeneutical point of view, repetition in SPL was used to raise stylistic effects, or, in this research, we call as a rhetorical device. This is in accordance with a previous theoretical study that mentioned repetition as a rhetorical device to deceive listeners (Feldman \& Landtshee, 2000). Since the early classical time, it has been known and accepted that politicians do play with the language and use it as a medium to create political intentions. It was also found in SPL.

The rhetorical aspect of SPL was the flexible space within the linguistic system. Wilson (1990) stated that the rhetorical device of repetition is offered by politicians, in this context, by Soekarno, to disguise their intentions and goals. Wilson believes that the political language is primarily based to influence people's political thoughts. What Wilson believes is the same as what we believe. Hermeneutically, SPL applied repetition as a device to blow and to influence Indonesian people's thoughts (cf. Dijk, 2006). We interpreted that repetition, semantically, relates to the experienced vision of reality according to the addressee and how Soekarno expresses it through words. The contextual function is tied with rhetorical structure, and how to make it appellative to the addressee, in accordance with the current situation.

Secondly, repetition style that applied in SPL, according to our research, was intended to be a spreading ideologies tool. The examination that has drawn us to this point of view is based on the phenomena of 'idea/ topic repetition' that found in SPL. In fact, Soekarno, in his political speech, used repetition style not only in lexicons or phrases, or clauses phenomena but also in explaining main ideas of each segment.

The repetition of the main ideas was a tool to plant ideologies of SPL. We believe that the main ideas of each segment, that repeated by Soekarno, are SPL's main ideologies. The ideologies are 1) unity as the most important thing for Indonesian, 2) revolution as Indonesian soul, and 3) Imperialism and Capitalism as Indonesian main enemy.

It has been revealed that Soekarno constructed 43 segments of 145 segments on the corpus to discuss 'unity as the most important thing for Indonesian'. The number dominates $30 \%$ of the whole text. Semantically, there are 119 lexicons that related to topic unity as the most important thing for Indonesian. The lexicons were used to persuade people to be united. Unity as the most important thing for Indonesian people was constructed by Soekarno for some reasons. Historically, Indonesia is multi races nation, multi religions nation as well as multi-cultural nations (Saidi, 2017). The situation makes the nation easier to be divided (Rosana, 2017).

The second main ideology that has been revealed by looking at the repetition strategy was a revolution as Indonesian soul. We have found that Soekarno constructed 39 segments to speak about revolution. It dominates $27 \%$ of the whole text. The general meaning of the segments are revolution itself must be kept doing by all Indonesian 
people. Both the first ideology and the second ideology were told repeatedly in SPL. Overall, there are 204 lexicons that semantically related to revolution topic. They are 164 lexicons 'revolution', and 40 lexicons 'revolutionary'.

The third main ideology that has been revealed, as we examined through the phenomena of topic repetition, was imperialism and capitalism as the main enemy of the Indonesian people. The construction of segments that speak about it was 31 segments. It dominates $22 \%$ of the whole text. Semantically, there are 76 lexicons that related to this third ideology. Using the lexicons, Soekarno constructed and the ideology into Indonesian people. Following is the chart of SPL ideologies presentation that examined by looking at the repetition of topics or ideas in the text.

\title{
SPL IDEOLOGIES
}

\author{
Unity as the most important thing \\ - Revolution as Indonesian soul \\ - Imperialism and capitalism as Indonesian main enemy \\ -Other topics
}

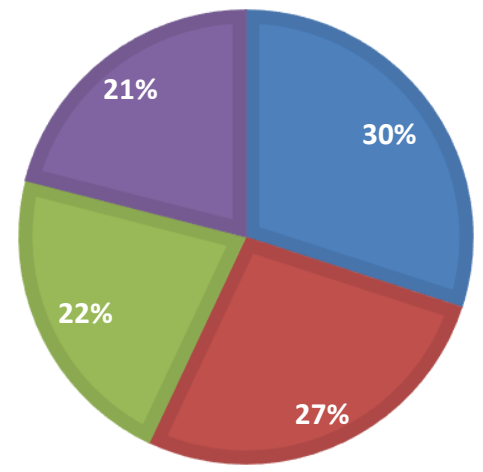

Figure 2. Chart of SPL Ideologies

Other topics, that has $21 \%$ portion on the topic, talk about (1) history of Indonesian nation, (2) thanksgiving for many positive aspects that have been given to Indonesian people, (3) spirit of struggling in gaining freedom, (4) meaning of freedom, (5) do not give up in facing difficulties, (6) nationalism, (7) spirit of independent, (8) the real leadership, (9) culture, (10) spiritual braveness, and (11) marhaenism ideology. The eleven ideas above, overall, are only $1.9 \%$ in the SPL. In other words, they are not dominant in the text. The dominant ideas, or the main ideologies, are only 'unity as the most important thing for Indonesian', 'revolution as Indonesian soul', and 'Imperialism and Capitalism as Indonesian main enemy', that can be revealed by examining repetition in SPL.

\section{Conclusion}

After discussing the repetition style that used by Soekarno, and presenting our analysis of the whyness, we conclude some points as follow. First, the political language in Indonesia, in this case, SPL, is characterized by the form of repetition. This form has dominated the text in SPL. Second, Soekarno, as the Asian politician, as well as the founder and the first president of Indonesia, used repetition as a rhetorical device, and as the vehicle of ideologies, that is to plant SPL's ideologies into all Indonesian people. Third, we believe that the findings of this research are important findings for Indonesian people since the ideologies that have been revealed by examining repetition phenomena of SPL, we hope, can be used as historical roots for the nation of Indonesia. Even though the last conclusion seems not too appropriate with the main aim of this research, we keep deciding to present it for the humanistic purpose.

The findings, especially about the ideology of SPL that implemented through repetition, are important for Indonesia because it is difficult to be denied that Pancasila ideology, as the foundation of Indonesia state ideology, is facing a threat nowadays. Some radicalism ideologies like Khilafah ideology, or ISIS ideology, are tried to be

\footnotetext{
Latupeirissa, D. S., Laksana, I. K. D., Artawa, K., \& Sosiowati, I. G. A. G. (2018). Repetition in Indonesian political language. International Journal of Linguistics, Literature and Culture, 4(6), 72-80. 
implemented by some people in Indonesia (Mohamed, 2010; Al Amin, 2012; Huda, 2014; Jones, 2015). It is a dangerous thing for the Indonesian people. Therefore, we hope the finding of Soekarno's ideology can be used as a mirror, as well as a root, to preserve Pancasila ideology.

The last, the research findings also reveal a fact that not all politician, especially Indonesian politician, use language, in this case, repetition, to deceive people. While some politician uses political language to cheat and to 'grab' other people using rhetorical device and repetition, Soekarno used language that is as a rhetorical device and a vehicle of ideology, to build and to preserve the nation of Indonesia. This is why we stated that the phenomena of repetition in SPL must be a mirror for other politicians.

Conflict of interest statement and funding sources

The authors declared that they have no competing interest. The study was financed by the Ministry of Research, Technology and Higher Education.

Statement of authorship

The authors have a responsibility for the conception and design of the study. The authors have approved the final article.

\section{Acknowledgments}

As this research is the part of a dissertation, I, as the first author, deliver my special gratitude to the team of promotor as well as to the rector of Universitas Udayana Denpasar for their advice, criticism, motivation, appreciation, and moral support, so that this research can be accomplished. 
References

Al Amin, A. R. (2012). Membongkar Proyek Khilafah Ala Hizbut Tahrir Indonesia (HC). Lkis Pelangi Aksara. https://books.google.co.id/books?hl=en\&lr=\&id=zdBqDwAAQBAJ\&oi

Corruption Perceptions Index. (2017). Indonesia Corruption index by Transparency International in https://tradingeconomics.com/indonesia/corruption-index

Fairclough, N. (1995). (1995a) Media Discourse. London: Edward Arnold.

Fairclough, N. (1995). 1995: Critical discourse analysis: the critical study of language. London: Longman.

Fairclough, N. (2001). Language and power. Pearson Education. http://www.academia.edu/download/25055352/(Language_In_Social_Life_Series_)Norman_FaircloughLanguage_and_Power_(Language_in_Social_Life)(1989).pdf

Fairclough, N. (2003). Analysing discourse: Textual analysis for social research. Psychology Press. https://books.google.co.id/books?hl=en\&lr=\&id=5-gXEMPINsEC\&oi

Fairclough, N. (2005). Peripheral vision: Discourse analysis in organization studies: The case for critical realism. Organization studies, 26(6), 915-939. https://doi.org/10.1177\%2F0170840605054610

Fairclough, N. (2007). Discourse and contemporary social change (Vol. 54). Peter Lang. https://books.google.co.id/books?hl=en\&lr=\&id=4RQd8JvuKjwC\&oi

Feldman, O. (Ed.). (2000). Beyond public speech and symbols: Explorations in the rhetoric of politicians and the media. Greenwood Publishing Group. https://books.google.co.id/books?hl=en\&lr=\&id=uS3c5xC4YaQC\&oi

Huda Ismail, N. (2014). To Stop ISIS in Indonesia, Target the Young and Reform Prisons. Jakarta Globe.

Jones, S. \& Solahudin.(2015). ISIS in Indonesia. Southeast Asian Affairs 2015, 154-163. ISEAS-Yusof Ishak Institute.

KPK, T. P. L. T. (2016). Laporan Tahunan 2015 Menolak Surut. Jakarta: Komisi Pemberantasan Korupsi.

Lema, R. K., Robot, M., \& Kosmas, J. (2018). News text on fire extinguishing service. International Journal of Linguistics, Literature and Culture, 4(5), 31-40. https://doi.org/10.21744/ijllc.v4n5.291

Mantzavinos, C. (2005). Naturalistic hermeneutics. Cambridge University Press. https://books.google.co.id/books?hl=en\&lr=\&id=7AMr8-J9aBUC\&oi

Melvin, J. (2017). Mechanics of Mass Murder: A Case for Understanding the Indonesian Killings as Genocide. Journal of Genocide Research, 19(4), 487-511. https://doi:10.1080/14623528.2017.1393942.

Mohamed Osman, M. N. (2010). Reviving the Caliphate in the Nusantara: Hizbut Tahrir Indonesia's Mobilization Strategy and Its Impact in Indonesia. Terrorism and Political Violence, 22(4), 601-622. https://doi.org/10.1080/09546553.2010.496317

Rosana, E. (2017). Eksistensi pancasila sebagai kontrak sosial umat beragama. Jurnal tapis, 13(2), 1-17. http://dx.doi.org/10.24042/tapis.v13i2.2031

Sa'idi, R. (2017). Urgensi menjaga kemajemukan dan toleransi dalam era demokrasi. Jurnal tapis, 13(2), 74-90. http://dx.doi.org/10.24042/tapis.v13i2.2035

Siswo, I. (2014). Panca Azimat Revolusi: Tulisan, Risalah, Pembelaan, \& Pidato Sukarno 1926- 1966. Jakarta: KPG

Tannen, D. (2007). Talking voices: Repetition, dialogue, and imagery in conversational discourse (Vol. 26). Cambridge University Press. https://books.google.co.id/books?hl=en\&lr=\&id=Mm3Yh17h7SIC\&oi

Van Dijk, T. A. (2006). Discourse, context and cognition. Discourse studies, 8(1), 159-177. https://doi.org/10.1177\%2F1461445606059565

Wilson, J. (1990). Politically speaking: The pragmatic analysis of political language. Basil Blackwell.

Latupeirissa, D. S., Laksana, I. K. D., Artawa, K., \& Sosiowati, I. G. A. G. (2018). Repetition in Indonesian political language. International Journal of Linguistics, Literature and Culture, 4(6), 72-80. https://doi.org/10.21744/ijllc.v4n6.427 


\section{Biography of Authors}

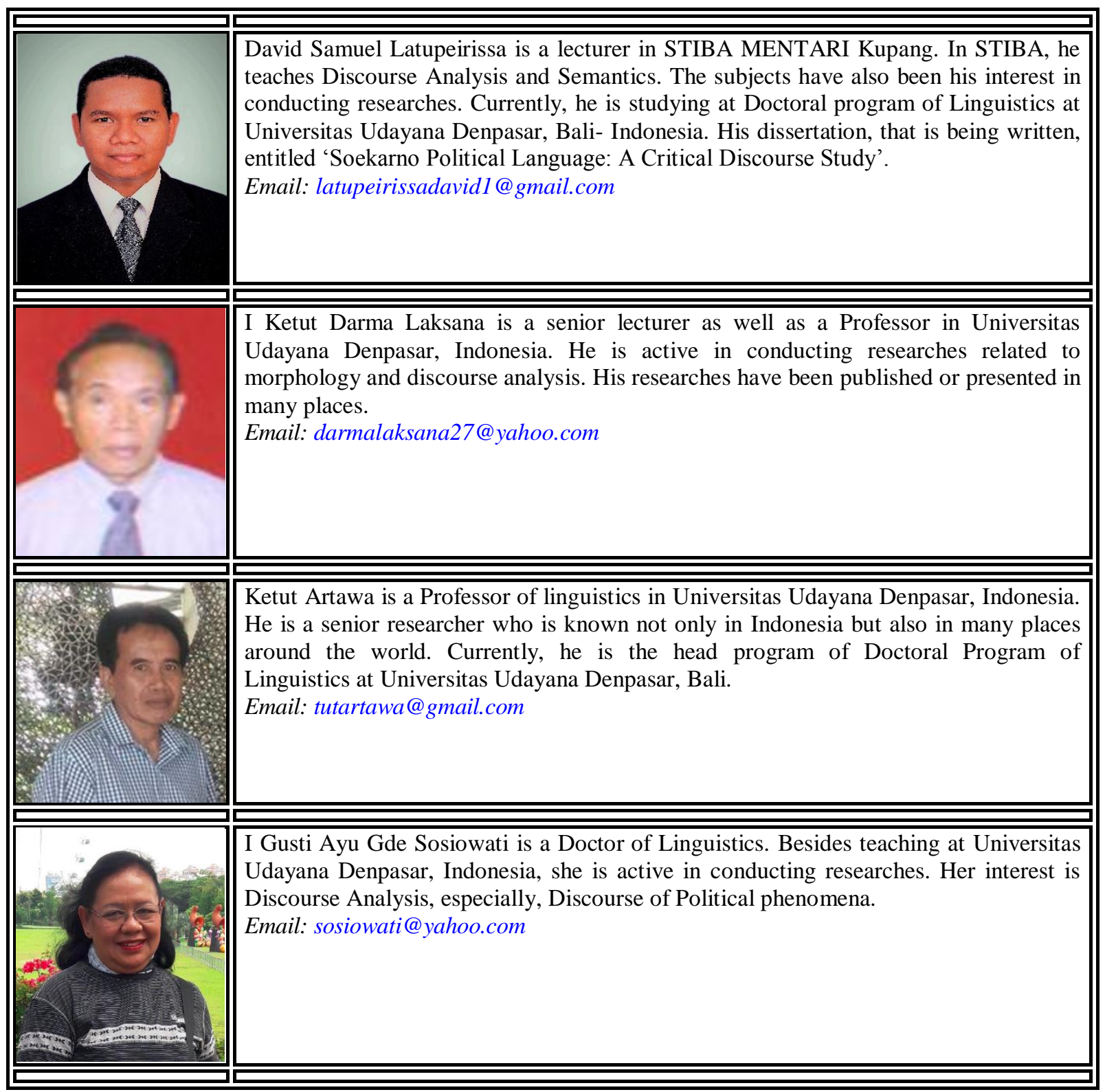

